\title{
Designing a digital pedagogical pattern for improving foreign language learners' oral proficiency
}

\begin{tabular}{|c|c|}
\hline \multicolumn{2}{|c|}{$\begin{array}{l}\text { Authors: } \\
\text { Carina Grobler } \\
\text { Tom F.H. Smits }\end{array}$} \\
\hline \multicolumn{2}{|c|}{$\begin{array}{l}\text { Affiliations: } \\
\text { }{ }^{1} \text { Department of French, } \\
\text { North-West University, } \\
\text { Potchefstroom Campus, } \\
\text { South Africa }\end{array}$} \\
\hline \multicolumn{2}{|c|}{$\begin{array}{l}{ }^{2} \text { Antwerp School of } \\
\text { Education, Universiteit } \\
\text { Antwerpen, Belgium }\end{array}$} \\
\hline \multicolumn{2}{|c|}{$\begin{array}{l}\text { Research Project no.: } \\
\text { NWU-00074-14-A7 }\end{array}$} \\
\hline \multicolumn{2}{|c|}{$\begin{array}{l}\text { Corresponding author: } \\
\text { Carina Grobler, } \\
\text { carina.grobler@nwu.ac.za }\end{array}$} \\
\hline \multicolumn{2}{|c|}{$\begin{array}{l}\text { Received: } 14 \text { Jan. } 2016 \\
\text { Accepted: } 08 \text { June } 2016 \\
\text { Published: } 29 \text { Sept. } 2016\end{array}$} \\
\hline \multicolumn{2}{|c|}{$\begin{array}{l}\text { How to cite this article: } \\
\text { Grobler, C. \& Smits, T.F.H., } \\
\text { 2016, 'Designing a digital } \\
\text { pedagogical pattern for } \\
\text { improving foreign language } \\
\text { learners' oral proficiency', } \\
\text { Literator 37(2), a1273. http:// } \\
\text { dx.doi.org/10.4102/lit. } \\
\text { v37i2.1273 }\end{array}$} \\
\hline \multicolumn{2}{|c|}{$\begin{array}{l}\text { Copyright: } \\
\text { (C) 2016. The Authors. } \\
\text { Licensee: AOSIS. This work } \\
\text { is licensed under the } \\
\text { Creative Commons } \\
\text { Attribution License. }\end{array}$} \\
\hline \multicolumn{2}{|c|}{ Read online: } \\
\hline 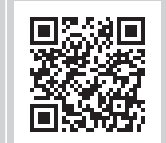 & $\begin{array}{l}\text { Scan this QR } \\
\text { code with your } \\
\text { smart phone or } \\
\text { mobile device } \\
\text { to read online. }\end{array}$ \\
\hline
\end{tabular}

South African undergraduate foreign language students need more opportunity to practise their oral language skills. Not only do appeals to focus more on oral productive skills feature in scholarly literature (Delena-le Roux 2010), it is also one of the main conclusions from a survey among beginner students of French at the Potchefstroom Campus of North-West University (South Africa). It was therefore necessary to design a teaching and learning intervention, specifically aimed at improving beginner students' oral communication skills in French. Laurillard's (2012) Conversational Framework inspired the design of a digital pedagogical pattern (DPP), consisting of context and pedagogy descriptors for the development of foreign language learners' oral communication skills. The Conversational Framework analyses formal learning and challenges the use of new technologies in learning. The implementation process of a DPP for the development of students' (French) oral skills involved three cycles, each with specific outcomes and three groups of participants: the control group and two experimental groups. Field-testing the proposed DPP provided important insights which should be integrated in the design of subsequent digital pedagogical patterns in the specific context: limiting the participant groups to two; decreasing the number of interventions to be implemented in the limited teaching time of a semester; ensuring that each step adheres to the requirements of the Conversational Framework. Student results from the learning interventions in future studies should reveal which intervention better promotes oral communication skills.

Die ontwerp van 'n digitale pedagogiese patroon vir die verbetering van leerders se mondelinge kommunikasievaardighede. Suid-Afrikaanse voorgraadse vreemdetaalstudente het meer geleenthede nodig om hulle mondelinge kommunikasievaardighede te oefen. Nie net lewer die akademiese literatuur 'n pleidooi vir meer klem op mondelinge vaardighede nie (Delena-le Roux 2010), dit is ook een van die sentrale gevolgtrekkings uit 'n opname onder beginnerstudente wat Frans neem by die Potchefstroomkampus van die NoordwesUniversiteit (Suid-Afrika). Dit was dus noodsaaklik om 'n onderrig- en leerervaring te ontwerp wat daarop gemik is om beginnerstudente se mondelinge kommunikasievaardighede in Frans te verbeter. Laurillard (2012) se Gespreksraamwerk was die inspirasie vir die ontwerp van ' $n$ digitale pedagogiese patroon (DPP) wat bestaan uit konteks en pedagogiese beskrywers ten einde vreemdetaalleerders se mondelinge vaardighede te ontwikkel. Die Gespreksraamwerk analiseer formele leer en die struikelblokke met die gebruik van nuwe tegnologieë in leer. Die implementeringsproses van ' $\mathrm{n}$ DPP vir die ontwikkeling van die mondelinge vaardighede van studente (in Frans) het drie siklusse, elk met sy eie uitkomste, en drie groepe deelnemers - die kontrolegroep en twee eksperimentele groepe - behels. Die toetsing van die voorgestelde DPP het belangrike insigte gebied wat geïntegreer behoort te word in die ontwerp van toekomstige digitale pedagogiese patrone vir die spesifieke konteks: deelnemersgroepe behoort tot twee beperk te word; leerervarings wat uitgevoer word tydens die beperkte onderrigtyd van 'n semester behoort verminder te word; daar moet verseker word dat elke stap van die leerervaring voldoen aan die vereistes van die Gespreksraamwerk. Studente-uitslae van die leerervarings in toekomstige studies behoort te onthul watter siklus die beste bydra tot die verbetering van mondelinge kommunikasievaardighede.

\section{Introduction}

The present article will discuss the development process of a teaching and learning intervention with the aim of improving the oral proficiency of beginners in a foreign language by looking at the design and implementation of a series of learning activities. According to Savignon (2001) twentyfirst century communicative language teaching needs to cater for the collaborative nature of learning and for the interrelatedness of language skills (reading, listening, speaking and writing). 
Teaching a foreign language, therefore, implies a combined focus on formal accuracy, on meaning (through realistic, e.g. task-based, language practice), on positive affective stimuli (through self-expression and self-discovery) and on learner autonomy.

In view of these methodological objectives, developing oral skills may be seen as posing a considerable challenge to both teachers and learners, because real-life productive language use, with attention to form and simultaneously allowing time for uninhibited self-expression, is no matter of course. Nevertheless, oral language production deservedly is a central component of communicative foreign language teaching, with speaking fluently as one of today's most eminent teaching objectives (Eisenmann \& Summer 2012). As a means to handle cross-cultural and -linguistic diversity especially within contexts where literacy might pose an obstacle, such as the African continent - oral communication skills are vital to social participation and emancipation. Closer to the classroom context, speaking skills have shown their value through studies demonstrating that active oral participation is beneficial to foreign language learning in general (Pica et al. 1996). This will come as no surprise if one considers the skill's concomitant opportunities to engage in interaction, which constitutes the cornerstone for learning in social constructivism. In the South African context in which this study is situated, it is thus crucial to find a way to promote and improve oral language production, while considering a methodology that is rooted in local/national culture (Sato 1982; Harmer 2006) and encourages learners to speak in the language classroom (Simons \& Decoo 2007).

The need for increasing time spent on spoken interaction and for improving students' oral proficiency in foreign languages is obviously not limited to the South African context. Studies on how to better oral proficiency in second and foreign languages have been done - and are still conducted today in many cultures worldwide: Vitienè and Mičiulienè (2008) in Europe; Bakar, Latiff and Hamat (2013); Yaikhong and Usaha (2012); Murakami, Valvona and Broudy (2012) in Asia, and Gleason and Suvorov (2011); Tsutsui, Kato and Mohr (1998); Warschauer (1996); Laborda (2009) in the United States of America. From the study of Helmke et al. (2007) we know that all too often learners get very little opportunity to practise their oral skills in foreign language classes. The fact that class size reduction has a significant influence on students' speaking proficiency and more precisely on pronunciation and information accuracy (Yi 2008), and that the quantity of target language input and feedback have an influence on language acquisition (Doughty \& Long 2003), has to be taken into account when addressing the problem of developing communication skills.

Swanson and Nolde (2011) propose the use of digital technologies to create out of class activities increase precious instructional time. The flexibility and potential of technologyenhanced learning tools in encouraging learners, as well as the tools' possibilities for differentiation (i.e. dealing with heterogenity), allow catering for different needs and styles
(Convery \& Coyle 1999). A further asset of information and communications technology (ICT) is its capacity to foster learner autonomy (Alm 2006), which is often referred to as the ultimate learning goal in communicative language teaching (Savignon 2001). Specifically relevant to the South African socio-economic context in particular is that, by instrumentalising ICT for teaching, it becomes possible to reach groups that may have difficulty attending (regular) programmes, have responsibilities as primary carers or other constraints and need flexibility to access technologyenhanced learning materials (Battezzati et al. 2004), or require tutoring (D'haese \& Valcke 2005).

A major advantage of ICT materials, especially for computerassisted language learning (CALL), is said to be that they facilitate interaction and language use. Chapelle (2010) refers to 'interaction' as 'any two-way exchanges'. This can be between two people, or between a person and the computer, as well as within the person's mind (Reinders \& White 2010). Adopting CALL allows one to create an environment in which learners can get meaningful intrinsic feedback, 'i.e. a natural or authentic consequence of their action in relation to the intended goal, from which they can work out how to improve it without teacher intervention' (Laurillard 2012: 170). This kind of feedback again enhances motivation and learner independence.

As confirmed by Volle's research (2005), most studies focus on learners with previous knowledge of the target language (Gleason \& Suvurov 2001; Murakami et al. 2012; Peng 2012; Arnold 2007; Al-Mansour \& Al-Shorman 2011; Gromik 2012, among others). In the context of the pilot study to be presented in this article, the need for individual development of oral proficiency is at its highest in beginners' classes where groups consist of large numbers of students making individual attention and practice impossible. Even the conversation tutorial classes consist of 20 or more students, which is not optimal. This study aims to aid in filling the gap in the literature on the development of beginner learners' skills in the target language.

The following section presents the theoretical framework for the process of developing a teaching and learning intervention that aims to improve the oral proficiency of beginners in a foreign language, the relevance of which is supported by a needs analysis. The section that follows explains the design of a technology-enhanced environment to foster oral skills. Thereafter the section focuses on the implementation of the learning activities. Challenges that arose from the various aspects of this development process will ultimately be addressed in the section 'Challenges, criticisms and suggestions'.

\section{Theoretical and methodological foundation of the study Research purpose}

The need for sound, evidence-based practices in foreign language learning and teaching where large groups of students are involved and the importance of developing oral 
production skills were the key motivators for the ongoing research project at the North-West University's (NWU) Potchefstroom campus (South Africa).

\section{Needs analysis: Perceived relevance of skills teaching}

At the onset of the pilot study a needs analysis survey on the perceived status of oral skills was administered at the end of the first week of class in the 2014 academic year. It involved students aged between 18 and 22 who were registered for the FREN111 module - a beginners' course in French as a foreign language. A total of 71 respondents took part in the survey. Male participants numbered 13 and 58 participants were female. Of these participants 64 had no previous knowledge of French.

A selection of four skills was listed in the survey: listening, reading, writing and spoken interaction, a subcategory of the skill 'speaking', which seemed too general for the purpose of this enquiry. 'Spoken production' (i.e. monologue) is the other subcategory of 'speaking' as defined by Chenard and Beya (2007), and seemed dissociated from the goals of beginner learners of a foreign language. The group listed spoken interaction as the most important. The majority of respondents ( $N=45$ or $63 \%$ ) listed this skill as their first priority. This correlates with Volle (2005) and Swanson and Nolde (2011) where $62 \%$ of learners rated speaking as the most important language skill. When looking at genderspecificity, the results stay more or less the same: out of the 58 female respondents, 37 considered oral communication to be the most vital foreign language skill, compared to eight out of 13 male respondents. Outdistanced by spoken interaction, the other skills remain within close proximity of each other: reading (favoured by 11 of 71 respondents), listening (nine respondents) and writing (six respondents).

When asked which aspect of language learning should receive special attention, 31 out of the 71 respondents (44\%) specifically mentioned pronunciation as an important aspect, worthy of particular attention. Again these results match Swanson and Nolde's results that report that $43 \%$ of students rank pronunciation as the most important variable when making audio recordings (2011). This links with the positive influence that teaching a smaller number of learners has on learners' pronunciation of the language (Yi 2008). The support for oral interaction concurs with the findings of a study at the University of Cape Town (UCT), South Africa's leading university in the domain of teaching French as a foreign language, stating that undergraduate students need more opportunity to practise spoken French (Delena-le Roux 2010).

\section{Pilot study: A teaching and learning intervention to improve oral proficiency}

At the same time as the survey and in the capacity of the pilot study, a DPP (Laurillard \& McAndrew 2003) was designed within Laurillard's (2012) Conversational Framework theory, with the aim of verifying the extent to which the proposed DPP's structure and design meet the requirements of the
Conversational Framework (CF) and the DPP framework and to confirm the viability of an application of the study's experimental design in the NWU context.

The CF serves to challenge the use of old and new technologies in learning by describing what is needed to create an effective, i.e. motivating and enabling, learning design (Laurillard 2008) and therefore can be used as a design analysis tool. It seeks to 'use the salient ideas in the principal theories of learning to give us the basis for understanding how to design teaching and learning now that digital technologies are making more impact on learning' (Laurillard 2012:93ff).

The pilot study - and any related studies conducted in future - does not aim to expand the intended learning outcomes by including competence in using technology for certain students only, but to better students' performance in the area of oral proficiency in French. It is hoped, therefore, that Chapelle's (2010:70) reservation about studies offering 'only limited insights' will be disproven. Chapelle and many other scholars are correct when questioning the (added) value of e-learning tools when rashly deployed in technology-driven teaching methods. A pedagogy-driven approach differs from a technology-driven one by being theoretically grounded. In short, a pedagogy-driven approach implies providing the technological tools after having identified the pedagogicdidactic requirements of the educational setting and the most appropriate method for learning. The CF offers such a model for designing the environment of teaching and learning. The concept of pedagogical patterns, such as the ones developed in the pilot study and discussed in this article, serves the purpose of providing 'a way to articulate, test and share the principles and practice of teaching that builds our knowledge of how to use digital technologies' (Laurillard 2012:102). Pedagogical patterns are uniformly structured descriptions of a teacher's method for solving a recurrent problem (Mor \& Winters 2007). They consist of context and pedagogy descriptors (cf. Table 1 and Table 2 in the next section) allowing teachers to share their pedagogic ideas in a 'principled way appropriate for a design science' (Laurillard 2012:215) and to ensure that 'pedagogy descriptors are organized to make the sequence of activities prominent' (Laurillard 2012:215). The pattern becomes 'digital' when the physical resources and tools are replaced by digital ones. This is done to provide students with better quality feedback from the digital environment.

In the case of developing the oral communication skills for beginners in a foreign language, the physical resources and tools that have been referred to above are enveloped within the lecturer and the peers attending a face-to-face conversation class in groups of up to 20. The digital resources that replace the lecturer (and peers to a certain extent) in the proposed DPP, include the learning-management system (LMS) (e.g. Sakai) and a software package (Papotons!) designed for the purpose of promoting the development of the student's oral communication skills.

Laurillard (2012) suggests linking a pedagogical pattern to the criteria of a framework to ensure the effectiveness of the 
pedagogical pattern. The comparative pedagogical power of a pattern can thus be demonstrated by mapping it to the learning cycles in the $\mathrm{CF}$, a framework that will 'motivate or enable the learner to generate their articulations and actions that modulate their concepts and practice' (Laurillard 2012:214)

The pattern that will be discussed in the next section is thus based on the criteria explained in Laurillard's (2012) CF (see Figure 1) by 'designing a teaching-learning environment for learners that provides design elements for each of the activities in each teacher or peer communication, practice and modeling cycle' (Laurilllard 2012:95). The CF (cf. Figure 1) provides a theoretical framework that directs the development of a pedagogydriven approach and provides an environment in which a digital pedagogical pattern (DPP) can be developed and evaluated.

The CF stresses these design elements as inherent to teaching - 'teaching should itself be an iterative process of learning' (Laurillard 2012:80) - and is applicable to learning through acquisition, inquiry, practice, production, discussion and collaboration. Constructionism - a form of

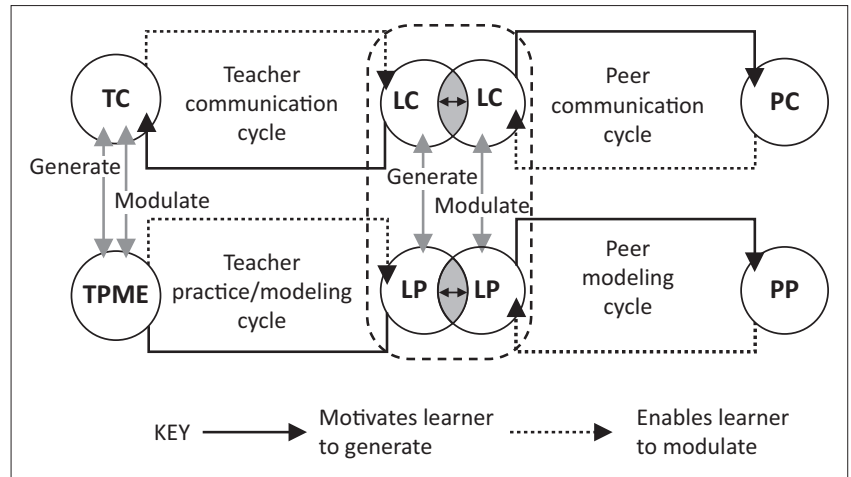

Source: Laurillard, D., 2012, 'Teaching as a design science: Building pedagogical patterns for learning and technology', Routledge, New York, NY

Note: The learner learning through interaction involving peers' concepts and practice, exchanging concepts and the outputs of the practice.

TC, teacher's conceptual organisation (class presentation, book, hand-out, etc.); $L C$, learner's concepts; LP, learner's practice; PC, peer's concepts; PP, peer's practice; TPME, teacher practice or modelling environment; arrows indicates iterative links.

FIGURE 1: An adapted visual representation of Laurillard's Conversational Framework. constructivism - is the learning theory that underpins this framework. The central idea of Constructionism is that:

... learners learn about some aspect of the world not directly from the teacher, but through attempting to build something in it, and in the process of doing so develops the understanding of underlying concepts (Laurillard 2012:165).

\section{The design of a digital pedagogical pattern for developing oral communication skills}

The model for a DPP developed in accordance with the CF theory consists of the following elements (Laurillard 2012:95).

Teacher communication cycle:

- TCC1: Access to teacher's concepts

- TCC2: The means to articulate their concepts and reflections of practice

- TCC3: Extrinsic feedback on questions or articulations of their concepts

Teacher practice cycle:

- TPC1: A practice environment that facilitates their actions

- TPC2: Extrinsic feedback on their articulations of actions

Teacher modelling cycle:

- TMC1: A modelling environment that elicits their actions

- TMC2: Intrinsic feedback on their actions from the model

Peer communication cycle:

- PCC1: Access to peers' concepts

- PCC2: The means to articulate their concepts and reflections on practice

- PCC3: Extrinsic feedback from peers on articulations of their concepts

Peer modelling cycle:

- PMC1: Sharing practice outputs with peers

- PMC2: Access to peer's outputs as a model for their practice

TABLE 1: Context descriptors, that is 'what the pattern covers, whom it is for, and what it tries to do'.

\begin{tabular}{lll}
\hline Context descriptors & Meaning of descriptors & Details \\
\hline Origin & Provenance or designer of the pedagogical pattern & School of Languages, NWU, South Africa.
\end{tabular}

Summary Teaching content and teaching method

Students are introduced to the goal of presenting themselves and providing information about their immediate environment in French and how to achieve it. They then practise the skill of expressing themselves orally using the practice and modelling environments provided and revise their approach in light of feedback.

\begin{tabular}{|c|c|c|}
\hline Topics & Keyword(s) & $\begin{array}{l}\text { Present yourself on a basic level, provide information about your immediate environment and ask } \\
\text { questions to obtain basic information from someone else. }\end{array}$ \\
\hline Learning outcome & Learning objective & $\begin{array}{l}\text { To be practised in the skill of presenting themselves and providing information about their } \\
\text { immediate environment in French and able to improve their own performance in achieving this goal. }\end{array}$ \\
\hline Rationale & Approach or pedagogical concept & Learning through acquisition, inquiry, discussion, collaboration \& practice. \\
\hline Duration & Time spent on teaching and learning & Three cycles including different sessions spread over a 13 week period (1 semester). \\
\hline Learner characteristics & School-related features of the target audience & Beginner students in French (module FREN111). \\
\hline Setting & Features of the learning environment & Face-to-face, LMS, personal PC/PC lab. \\
\hline Resources and tools & & $\begin{array}{l}\text { Hand-outs, textbooks, Papotons! software package (cf. 'Implementing different digital pedagogical } \\
\text { patterns: experimental and control groups', Step 3), LMS. }\end{array}$ \\
\hline
\end{tabular}

Source: Laurillard, D., 2012, Teaching as a design science: Building pedagogical patterns for learning and technology, p. 213, Routledge, New York, NY 
TABLE 2: Pedagogy descriptors, i.e. 'what [the pattern] does, and how and why it works'.

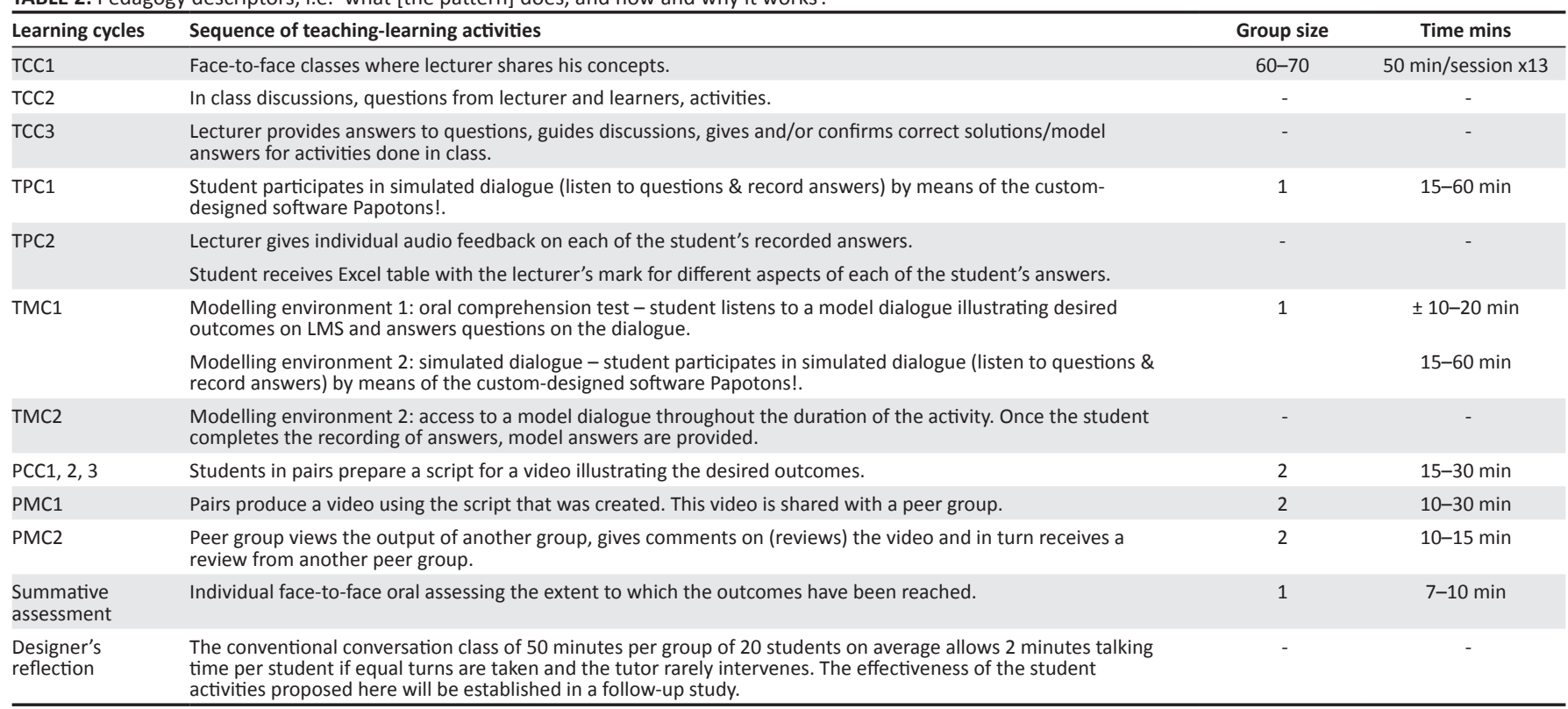

TCC, Teacher communication cycle; TPC, Teacher practice cycle; TMC, Teacher modelling cycle; PCC, Peer communication cycle; PMC, Peer modelling cycle.

Source: Laurillard, D., 2012, Teaching as a design science: Building pedagogical patterns for learning and technology, p. 213, Routledge: New York, NY

The activities designed for developing the oral communication skill of beginners in French are mapped out according to Laurillard's (2012) proposed format for a pedagogical pattern - including both context and pedagogy descriptors in Table 1 and Table 2 in order to share pedagogic ideas and to bring the sequence of the activities to the fore.

The sequence of learning activities described in Table 2 above served as the basis for three teaching and learning interventions with beginner students in French over the course of a semester with 13 weeks teaching time. The next section provides a detailed discussion of the structure and implementation of these interventions.

\section{Digital pedagogical patterns: Design and implementation \\ Design of a digital pedagogical pattern for improving oral communication skills}

The DPP described in Tables $1 \& 2$ was broken up in six steps which regrouped its different constituting elements in the following way.

\section{Step 1: Face-to-face classes}

(Teacher communication cycle 1, 2, 3)

In Step 1 language-related communicative competences are introduced inductively to students during traditional face-to-face classes. These competences have the following components: linguistic competences (ex: lexical and syntactical knowledge); sociolinguistic competences (ex: rules of politeness); pragmatic competences (ex: speech acts) (Council of Europe 2011:22).

\section{Step 2: Model dialogue (Teacher modelling cycle 1)}

Eisenmann and Summer (2012:146) emphasise the importance of giving students 'opportunities to listen to specific types of model speaking tasks'. Thus after \pm 4 weeks of teaching time, students continue in Step 2 during which they access a recording of a model dialogue via the NWU's LMS. The dialogue demonstrates the concepts introduced in Step 1 and the outcomes that should be mastered at the end of the learning cycle, in this way merging the competencies of reading and writing with that of speaking. This is followed by a short quiz administered on the LMS, testing the students' understanding of the content of the model dialogue.

\section{Step 3: Simulated conversation (Teacher practice cycle 1; Teacher modelling cycle 1,2 )}

In Step 3 students record their individual contributions to a basic Question and Answer (Q\&A) session or simulated conversation (Council of Europe 2001:178). Technology such as Nihongo Partner ${ }^{1}$, Wimba voice ${ }^{2}$ and Didier's Labo de langue $^{3}$ are not available to our students. We therefore use a custom-designed software package (Papotons!) consisting of three different components to prepare this step of the learning cycle:

- Create: the lecturer creates the Q\&A activity.

- Reply: students answer the questions created by the lecturer.

- Feedback: the lecturer gives audio feedback on students' work.

In this process students listen to the first pre-recorded question as many times as they wish. They then have the opportunity to record an answer to this question. They listen to their recorded reply and either choose to save it and

1.A multi-media software programme allowing language learners to master model dialogues and to interact with pre-recorded onscreen partners.

2.An online platform supporting the communicative styles of language learning by providing different ways of listening to, writing in and speaking a foreign language.

3.An online tool available to users of the publisher's textbooks that provides a space for communication with and among learners. 
continue to the next question or to re-record the answer. The number of tries is unlimited. The students then move on to the next question in the series. If they are unsure about the meaning of the question to which they are supposed to respond or of the format of the answer, the model dialogue used in Step 2 can be consulted to obtain intrinsic feedback on a student's performance. This provides a practice environment that supplies:

exercises within the learner's zone of proximal development [...] providing the formative intrinsic feedback that enables learners to interpret results and work out how to improve for themselves the essence of the learning process (Laurillard 2012:73).

After the Q\&A part of the activity, a number of appropriate words are provided and students are asked to choose some of the words and to formulate a question either using the word itself or referring to the theme represented by the word.

A second survey conducted at the end of the pilot, done in 2014, showed that students re-recorded their answers multiple times - as did the learners in Swanson and Nolde's study (2011) - thus increasing the time spent on creating language. Twenty of the 27 respondents re-recorded their answers two or three times, whereas six students reportedly recorded their answers more than three times before being satisfied with the results. As time on task is an indicator for learning (Bransford, Brown \& Cocking as cited in Laurillard 2012), increased time on a task as demonstrated by the results of the survey should promote expertise.

At the end of the simulated dialogue, an audio-recording of an individual modelling the successful completion of the activity is provided before the students are required to rate their performance in four areas on a sliding scale, thus adhering to the recommendations of Eisenmann \& Summer (2012:418) to provide students 'with means of assessing their own performance'. Laurillard (2012:90) states that:

a modeling environment that models the task in such a way that the learner can see the result of their own actions in comparison with the intended model is one of the most powerful ways of learning, and enables the learner to 'learn without being taught.

The proposed self-assessment criteria include the measure to which the questions were understood, the completeness of the replies, the correctness of the replies, and lastly the quality of pronunciation (see Figure 2). As suggested in literature (Eisenmann \& Summer 2012), these assessment criteria are announced to the students on the LMS before they participate in step 3 - the simulated conversation.

Students then upload the completed 'dialogue' onto the LMS to allow the lecturer to listen to the production and to record individual feedback on students' performance in Step 4.

Step 3 involves 'responsive' oral output (Brown as cited in Pino-James 2013:28) i.e. short replies to questions which serve as a 'preliminary stepping stone' towards real communication (Abrams in Pino-James 2013:40). The DPP

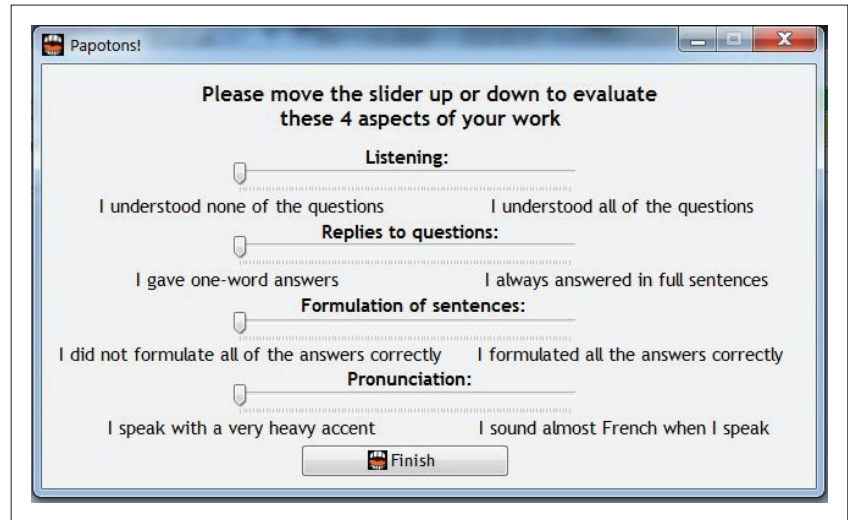

Source: Steyn, J. \& Grobler, C., 2016, Papotons! [computer software], NWU, Potchefstroom FIGURE 2: Self-assessment criteria. Screen shot of criteria for student selfassessment to be done after the simulated conversation.

thus gradually prepares students for a face-to-face communication situation described in Step 6.

Throughout the process, students have the opportunity to make use of different types of support: technical support (contact sessions in language laboratory, e-mail contact with software developers), facilitator (content support), and teacher support. Without such support, students tend to use fewer or inefficient learning strategies, motivation levels tend to be low and dropout rates high (Reinders \& White 2010).

\section{Step 4: Audio feedback (Teacher practice cycle 2)}

The feedback provided by the lecturer in this step implies informational feedback as defined by Dörnyei (1994:278), that is: 'feedback which comments on competence. The goal is not to judge the performance against external standards'. Comments on sentence structure, pronunciation, the meaning of the questions and advice on how to work towards the learning outcomes are recorded. An integrated sound file consisting of the lecturer's question, the student's response and the lecturer's feedback is thus produced. This file is made available to the student on the LMS.

Following are transcriptions representative of the type of feedback a student receives.

\section{Transcription A:}

Bonjour, je m'appelle Manon. Comment allez-vous? [Lecturer's question]

Bonjour, je m'appelle Marie. [short pause] Je suis bien. Et vous? [Student's response]

Merci Marie. Je vais très bien. [short pause] Just be careful when you answer the question on how you're doing. In French you say I'm going well. So you would say 'Je vais bien'. [Lecturer's feedback]

\section{Transcription B:}

Et vous vous levez à quelle heure le matin? [Lecturer's question] Je me levez à sept heures. [voice goes up at the end] [Student's response] 
OK. (short pause) If you want to say I get up at seven o'clock, you have to say 'Je me lève à sept heures'. 'Levez' is for 'vous'. [Lecturer's feedback; Words in bold represent emphasis.]

Students are required to do a short quiz on the individual feedback that has been made available to them on the LMS. The quiz includes questions like: 'How many times did you listen to the audio feedback?'; 'How useful was the lecturer's audio feedback?'; 'About which aspects did you learn most, thanks to the feedback?'; 'What would you like to change about the way the feedback is done?' This ensures that students listen to the feedback at least once and their reactions on the feedback help lecturers to adapt and improve their feedback.

\section{Step 5: Student videos (Peer communication cycle 1, 2, 3 and Peer modelling cycle 1, 2)}

This step introduces the first collaborative activity done in pairs and it is the next step in the series of activities succeeding the quiz, described in Step 4. It involves the production by students in pairs of a short video clip. Precise instructions were given as to the expected content of the video. Students mostly used their phones for recording as they are familiar with the video functionality.

Requiring a videotaped production prevented students from reading a script and ensures that this stage of the cycle does not change into a 'non-semantic read aloud practice' as referred to by Pino-James (2013:36). This could well be the case in the simulated dialogue part of the cycle described above. Although the benefits to this read aloud practice are acknowledged, it is believed that executing a video production will contribute more to the development of students' speaking skills.

The video clips are made available on the LMS where other students give advice and/or feedback and/or commentary on these productions. This adheres to Laurillard's (2012:89-90) advice to:

give learners the means to build an external representation of their knowledge to share with others; provide feedback that can guide modification of actions and the concepts that generated them.

The skills acquired in Steps 1-5 should facilitate interaction and language use and are subsequently put into practice during the next step.

\section{Step 6: Individual oral (Summative assessment)}

The last step of the cycle involves a one-on-one oral with the lecturer in an effort to bring it closer to 'real life' and give learners another opportunity to interact and communicate, which is esteemed to be of particular importance by Smith and Schulze (2013). The goal with this part of the process is in accordance with that of Eisenmann and Summer (2012:418) i.e. 'to determine whether the student can handle a simulated real-life situation'. This will also ensure that students cannot read their prepared written answers, like Volle suspects participants did in her study (2005). It eliminates another of the shortcomings of her study where participants took part in communication without visual clues.
This phase of the cycle also addresses the recurrent issue of the lack of interpersonal communication and real-time interaction when speaking by means of technology (Gleason \& Suvorov 2011; Pino-James 2013). The design takes into account Colpaert's (2013) call for smart design, with personalisation of the learning process, and teacher and peer feedback to the benefit of learners' oral proficiency. The oral assessment allows the lecturer to reformulate or repeat questions at a slower pace, to give advice and help students to understand. This adheres to the description of the competence expected of a user of the language at A1 level in the domain of spoken interaction as defined by the Common European Framework of Reference (CEFR):

I can interact in a simple way provided the other person is prepared to repeat or rephrase things at a slower rate of speech and help me formulate what I'm trying to say (Council of Europe 2011:26).

\section{Implementing different digital pedagogical patterns: Experimental and control groups}

In order to verify the suitability of the implementation of a study comparing a control group with two experimental groups in preparation for a more encompassing future study, students were randomly divided into three groups and underwent different interventions over the course of the semester. Intervention 1 (control group) consisted of the 'ideal' DPP described above. Participants in intervention 2 (experimental group 1) did not receive individual oral feedback on the simulated dialogue and intervention 3 (experimental group 2) omitted the production of a group video. At the end of each cycle every individual student underwent the same oral evaluation on the theme treated in the course of that cycle (see Figure 3).

These one-on-one orals require the 'same authentic, interactive language use promoted in the classroom so that there is a match between what is taught and what is tested' (Eisenmann \& Summer 2012:422). The orals are videotaped to create digital oral production artefacts. These artefacts are stored and could be used for comparison between subjects and to evaluate overall progress (cf. Swanson \& Nolde 2011:74).

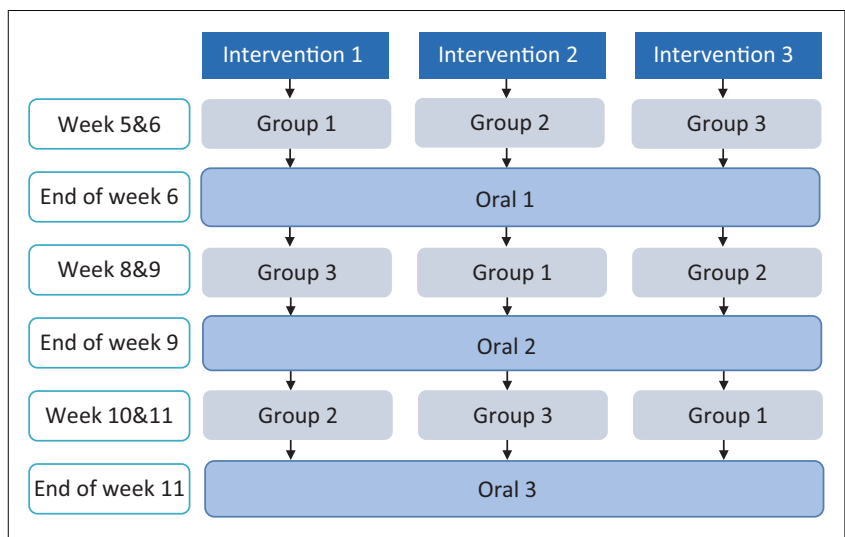

FIGURE 3: Structure of interventions. 


\section{Challenges, criticisms and suggestions}

The results of the pilot study are still to be analysed, but a number of challenges for design science research of this kind arose during this study. The following elements would have to be considered and rectified before launching a wider study of this type:

The first challenge is the sample size. Of the 71 students enrolled for this module in 2014, altogether 64 had no previous knowledge of French. As the participants are divided into three groups that undergo three different interventions, the size of the groups for 2014 was around 23. Groups got even smaller as the semester advanced as the fall-out rate over the previous three years (2012-2014) from the beginning of the first semester until the examinations at the end of the first semester was about $12 \%$. The duration of the study is limited to the first semester ( 13 weeks teaching time), as the fall-out rate from the first to the second semester is quite high $( \pm 39 \%)$. This would make the sample size considerably smaller during the second semester. To resolve this problem, one would have to consider a study with a control group and only one experimental group.

The amount of time available to implement the different interventions also supports the move from two experimental groups to one. Allowing more time to complete a cycle than provided in this pilot, will be crucial.

Implementing three successive cycles during the short period of 13 weeks teaching time means that each cycle had to be completed within a two-week period. This leads to a rapid and at times rushed execution of the activities which could lead to diminished participation from students. Not much time was available to make allowances in case of technical problems such as the unavailability of the LMS or problems with the Papotons! software. So it is recommended that two interventions are retained - the 'ideal' DPP and one deviation from this. The software designed for the purpose of this study would have to be adapted to ensure that an activity such as the one proposed in Step 3 (Simulated conversation) allows the students to compare the result of their actions with the model. This would mean that at the end of the simulated dialogue the students would be able to listen to their own answers one by one, followed by a model answer before they are asked to do a self-evaluation on their actions. This and other smaller issues concerning layout and functionality need to be addressed before launching follow-up studies.

The design of the 'ideal' DPP seems to be rather solid and coherent with the elements proposed by the CF. The structure of an activity such as the one in Step 2 (Model dialogue) would, however, have to be changed to ensure that students receive intrinsic feedback. This could be done by a system guiding the learner towards the correct response through elicitation and meta-linguistic cues that go beyond right or wrong type of feedback (Bañados 2006).

\section{Conclusion}

An inceptive student survey at South Africa's North-West University (Potchefstroom Campus) established the need for oral communication skills among foreign language students of French. National (Delena-le Roux 2010) and international studies (Volle 2005; Swanson \& Nolde 2011) support this outcome. Technology creates opportunities to foster oral foreign language proficiency without the risk of squandering instructional time and daunting (weaker) students. The study outlined in this article took Laurillard's (2012) CF as a theoretical and conceptual starting point for the design of a technology-enhanced, pedagogy-driven learning environment to acquire oral competencies. The CF provides an environment in which DPPs can be both developed and evaluated.

From test running the $\mathrm{CF}$ - constituting an opportunity to validate Laurillard's conceptual framework - several issues of concern have been identified, such as the required number of participants and the time available, which could potentially have an important impact on the quality of the pedagogical intervention. These limitations make it crucial to conduct future research in an effective and valid manner to establish guidelines for education researchers. Another contributing measure to establish guidelines for the methodology of CALL research in sub-optimal educational settings, amounts to executing the ADDIE educational engineering loop (Morrison et al. 2013). Hence, analysing the learning environment and formulating system requirements on the basis of epistemological, empirical, technological or other considerations will be the first step to follow the pilot study on which this article reported (cf. Colpaert 2006).

The implementation of the DPP yielded results that inform design researchers on changes and improvements to be made to both CALL design and its practical application. Continued research is necessary to ensure that the oral proficiency of students is improved optimally. In a subsequent study, the overall objective will be to implement different pedagogical interventions by means of an 'ideal' DPP - as described in this article - and pedagogical patterns that deviate from the ideal, with the aim of establishing and comparing the effectiveness of each of the three DPPs for improving foreign language learners' oral proficiency.

By implementing the different DPPs we should find out if and to what extent - a deviation from the 'ideal' pattern would influence the performance of beginner students of French as a foreign language. The results should give an indication of how to proceed in future and to what extent the proposed CF should be respected. Collecting and analysing data concerning student motivation and autonomy should also yield interesting results and would give an indication of the effectiveness of the implemented DPPs in this regard. 


\section{Acknowledgements Competing interests}

The authors declare that they have no financial or personal relationships which may have inappropriately influenced them in writing this article.

\section{Authors' contributions}

T.S. was the project leader and supervises the Ph.D. research, conducted by C.G., which includes the survey and DPP design. T.S. and C.G. authored different sections of the paper and prepared the manuscript for publication together.

\section{References}

Alm, A., 2006, 'CALL for autonomy, competence and relatedness: motivating language learning environments in Web 2.0', The JALT CALL Journal 3(2), 29-38.

Al-Mansour, N.S. \& Al-Shorman, R.A., 2011, 'The effect of computer-assisted instruction on Saudi University students' learning of English', Journal of King Saud University - Languages and Translation 24, 51- 56

Arnold, N., 2007, 'Reducing foreign language communication apprehension with computer-mediated communication: A preliminary study', System 35, 469-486. http://dx.doi.org/10.1016/j.system.2007.07.002

Bakar, N.A., Latiff, H. \& Hamat, A., 2013, 'Enhancing ESL learners speaking skills through asynchronous online discussion forum', Asian Social Science 9(9), 224-233. http://dx.doi.org/10.5539/ass.v9n9p224

Bañados, E., 2006, 'A blended-learning pedagogical model for teaching and learning EFL successfully through an online interactive multimedia environment', CALICO Journal 23(3), 553-550.

Battezzati, L., Coulon, A., Gray, D., Mansouri, I., Ryan, M. \& Walker, R., 2004, E-learning for teachers and trainers: Innovative practices, skills and competences, Office for Official Publications of the European Communities, Luxembourg.

Bransford, J.A., Brown, A.L. \& Cocking, R.R., (eds.), 2003, How people learn: Brain mind, experience and school, National Academy Press, Washington, D.C.

Chapelle, C. A., 2010, 'The spread of computer-assisted language learning', Language Teaching 43, 66-74. http://dx.doi.org/10.1017/S0261444809005850

Chenard, S. \& Beya, A.M., 2007, 'De la polyphonie à l'harmonie: le CECR', Le Français dans le Monde 351, 36-37.

Colpaert, J., 2006, 'Pedagogy-driven design for online language teaching and learning', Calico Journal 23(3), 477-497.

Colpaert, J., 2013, 'Sustainability \& research challenges in CALL', paper presented at WorldCall 2013, Glasgow.

Convery, A. \& Coyle, D., 1999, Differentiation and individual learners: A guide for classroom practice, Centre for Information on Language Teaching and Research, London.

Council of Europe, 2011, 'Common European framework of reference for languages: Learning, teaching, assessment', Retrieved on 13 February 2015 from http:// www.coe.int/t/dg4/linguistic/source/framework_en.pdf

Delena-le Roux, S., 2010, 'Le français à l'université en Afrique du Sud : Renouveler les formations en fonction des besoins des étudiants', French studies in Southern Africa : Le français en Afrique du Sud: une francophonie émergente? Special Issue $140,125-152$.

D'haese, I. \& Valcke, M., (eds.), 2005, Digitaal leren. ICT-toepassingen in het hoger onderwijs, LannoCampuso, Tielt.

Dörnyei, Z., 1994, 'Motivation and motivating in the foreign language classroom', The Modern Language Journal78(3), 273-284. http://dx.doi.org/10.1111/j.1540-4781. 1994.tb02042.x

Doughty, C.J. \& Long, M.H., 2003, 'Optimal psycholinguistic environments for distance foreign language learning', Language learning \& Technology 7(3), 50-80.

Eisenmann, M. \& Summer, T., 2012, 'Oral exams: Preparing and testing students', (in M. Eisenmann \& T. Summer, (eds.), 2012, Basic issues in EFL teaching and learning, Universitätsverlag Winter, Heidelberg, ( 415-428).
Gleason, J. \& Suvorov, R., 2011, 'Learner perceptions of asynchronous oral computermediated communication tasks using Wimba Voice for developing their L2 oral proficiency', in S. Huffman \& V. Hegelheimer, (eds.), The role of CALL in hybrid and proficiency', in S. Huffman $\&$. Hegelheimer, (eds.), The role
online language courses, lowa State University, Ames, IA.

Gromik, N.A., 2012, 'Cell phone recording feature as a language learning tool: a case study', Computers \& education 58, 223-230. http://dx.doi.org/10.1016/j. compedu.2011.06.013

Harmer, J., 2006, The practice of English language teaching, Pearson Education, Edinburgh.

Helmke, A., Helmke, T., Kleinbub, I., Nordheider, I., Schrader, F.-W. \& Wagner, W., 2007 'Die DESI-Videostudie: Unterrichtstranskripte für die Lehrerausbildung nutzen', Der fremdsprachliche Unterricht 90, 37-45.

Laborda, J.G., 2009, 'Using webquests for oral communication in English as a foreign language for tourism studies', Educational Technology \& Society 12(1), 258-270.

Laurillard, D., 2008, 'The teacher as action researcher: Using technology to capture pedagogic form', Studies in Higher Education 33(2), 139-154. http://dx.doi. org/10.1080/03075070801915908

Laurillard, D., 2012, Teaching as a design science: Building pedagogical patterns for learning and technology, Routledge, New York, NY.

Laurillard, D. \& McAndrew, P., 2003, 'Reusable educational software: A basis for generic learning activities', in A. Littlejohn, (ed.), 2003, Reusing online resources: A sustainable approach to e-learning, Kogan Page, London.

Mor, Y. \& Winters, N., 2007, 'Design approaches in technology-enhanced learning', Interactive Learning Environments 15(1), 61-75. http://dx.doi.org/10.1080/104 94820601044236

Morrison. G.R., Ross, S.M., Kalman, H.K., \& Kemp, J.E., (eds.), 2013, Designing effective instruction, Wiley, New York.

Murakami, C., Valvona, C. \& Broudy, D., 2012, 'Turning apathy into activeness in ora communication classes: Regular self- and peer-assessment in a TBLT programme', System 40, 407-420. http://dx.doi.org/10.1016/j.system.2012.07.003

Peng, J., 2012, 'Towards an ecological understanding of willingness to communicate in EFL classrooms in China', System 40, 203-213. http://dx.doi.org/10.1016/j. system.2012.02.002

Pica, T., Lincoln-Porter, F., Paninos, D., \& Linnell, J., 1996, 'Language learners' interaction: How does it address the input, output, and feedback needs of $L 2$ learners?', TESOL Quarterly 30(1), 59a - 84. http://dx.doi.org/10.2307/3587607

Pino-James, N., 2013, 'Exploring the benefits of ACMC for speaking development', The IALLT Journal 43(1), 25-63.

Reinders, H. \& White, C., 2010, 'The theory and practice of technology in materials development and task design', in N. Harwood, (ed.), 2010, Materials in ELT: Theory and practice, Cambridge University Press, Cambridge (58-80).

Sato, C., 1982, 'Ethnic styles in classroom discourse', in M. Hines \& W. Rutherford, ( eds.), On TESOL'81. Washington, DC: TESOL, 11-24.

Savignon, S.J., 2001, 'Communicative language teaching for the twenty-first century', in M. Celce-Murcia, (ed.), Teaching English as a second or foreign language, Heinle \& Heinle, Boston, (13-28).

Simons, M., \& Decoo, W, 2007, 'Cette peur d'ouvrir la bouche : comment vaincre I'anxiété dans l'apprentissage des langues ?', Le français dans le monde 352, 40-42.

Smith, B. \& Schulze, M., 2013, 'Thirty years of the Calico journal - Replicate, replicate, replicate', Calico Journal 30(1), i-iv. http://dx.doi.org/10.11139/cj.30.1.i-iv

Steyn, J. \& Grobler, C. , 2016, Papotons! [computer software], NWU, Potchefstroom.

Swanson, P.B. \& Nolde, P.R., 2011, 'Assessing student oral language proficiency: Costconscious tools, practices \& outcomes', The IALLT Journal 41(2), 72-88.

Tsutsui, M., Kato, M., \& Mohr, B., 1998, 'Closing the gap between practice environments and reality: An interactive multimedia program for ora communication training in Japanese', Computer Assisted Language Learning 11(2), 125-151. http://dx.doi.org/10.1076/call.11.2.125.5688

Volle, L.M., 2005, 'Analyzing oral skills in voice e-mail and online interviews', Language Learning \& Technology 9(3), 146-163.

Vitienè, N. \&, Mičiulienė, R., 2008, 'Application of criteria-referenced assessment and qualitative feedback to develop foreign language speaking in the context of e-teaching/learning', Quality of higher education (5), 152-171.

Warschauer, M., 1996, 'Comparing face-to-face and electronic discussion in the second language classroom', CALICO journal 13(2\&3), 7-26.

Yaikhong, K. \& Usaha, S., 2012, 'A measure of EFL public speaking class anxiety: Scale development and preliminary validation and reliability', English Language Teaching 5(12), 23-35. http://dx.doi.org/10.5539/elt.v5n12p23

Yi, H., 2008, 'The effect of class size reduction on foreign language learning: A case study', Language and Linguistics Compass 2(6), 1089-1098. http://dx.doi. org/10.1111/j.1749-818X.2008.00090.x 